\title{
Anaerobic co-digestion cow dung and corn stalk - effect of corn stalk pre-treated timing
}

\author{
Đồng phân hủy yếm khí phân bò và thân bắp - Ảnh hưởng của thời gian tiền xử lý thân bắp
}

\author{
NGUYEN Le Phuong ${ }^{1}$; LAM Thanh Ai ${ }^{1}$; NGUYEN Thi Diem Trang ${ }^{1}$; NGUYEN Huu Chiem ${ }^{1}$; \\ NGUYEN Vo Chau Ngan ${ }^{2}$ \\ ${ }^{1}$ Hau Giang Industrial Zones Authority, Hau Giang province, Vietnam; ${ }^{2}$ College of Environment and Natural Resources, Can Tho University, Can Tho city, \\ Vietnam
}

\begin{abstract}
The study was aimed to investigate the effect of corn stalk pre-treatment duration on biogas production when cow dung and corn stalk was co-digested in an anaerobic digestion. Corn stalks were pre-treated in different durations: 2days, 5-days, and 8-days before being added to cow dung into anaerobic co-digesters. The experiments were set up randomly by using triplicate batch anaerobic apparatus in $21 \mathrm{~L}$ containers that run in 60 -days. The mixing ratio between a corn stalk and cow dung was 50\%: 50\% (based on the volatile solid value of each material), but corn stalk was cut into small pieces with around $10 \mathrm{~cm}$ length, while the cow dung was air dried. The results of the study indicated that all operation parameters such as temperature, $\mathrm{pH}$, and alkalinity in the anaerobic batch were suitable for biogas production. The results showed that there was a significant improvement in total gas produced in the pre-treated 5-days treatment $(206.4 \pm 8.4 \mathrm{~L})$ compared to 2-days $(153.4 \pm 9.6 \mathrm{~L})$, and 8-days ones $(174 \pm 11.1 \mathrm{~L})$. The biogas yield of the pretreated 2-days, 5-days, and 8-days treatments were $392.7 \pm 9.8 \mathrm{~L} / \mathrm{kg} \mathrm{VS}$ fermented, $469.8 \pm 10.1 \mathrm{~L} / \mathrm{kg} \mathrm{VS}$ fermented and 497.1 $\pm 13.3 \mathrm{~L} / \mathrm{kg} \mathrm{VS}$ fermented, respectively, that was not significantly different (5\%). In all treatments, low concentration of methane in the beginning phase had been observed but increased and reached the optimum value for energy use after 10 days. The result of the study showed that it is preferable to have 5-days pre-treatment of corn stalk before the corn stalk is loaded to an anaerobic digester in combination with cow dung.
\end{abstract}

\begin{abstract}
Nghiên cứu này nhằm đánh giá ảnh hưởng của thời gian xử lý thân cây bắp lên năng suất sinh khi khi ủ phối trộn phân bò và thân cây bắp trong điều kiện yếm khí. Ba mức thời gian xử lý thân cây bắp được chọn là 2 ngày, 5 ngày, và 8 ngày. Các thí nghiệm được bố trí ngẫu nhiên trong các bình ủ yếm khi theo mẻ 21 L, vận hành trong 60 ngày liên tiếp và có 3 lần lặp lại. Nguyên liệu ủ được phối trộn theo tỷ lệ 50\% phân bò và 50\% thân bắp, trong đó thân bắp được cắt nhỏ cỡ $10 \mathrm{~cm}$. Kết quả thí nghiệm cho thấy tất cả các thông số $\mathrm{pH}$, nhiệt độ, độ kiềm của mẻ ủ đều phù hợp để vận hành. Lượng

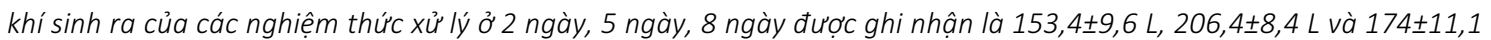

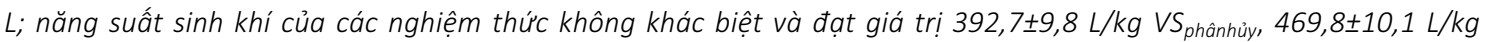

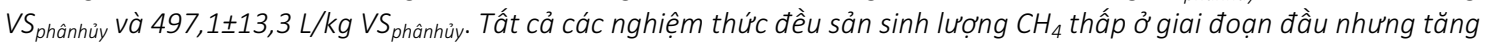
dần theo thời gian ủ và đạt hiệu quả sử dụng sau 10 ngày ủ. Kết quả cho thấy có thể chọn mốc thời gian 5 ngày để xử lý thân cây bắp trước khi đưa vào hầm ủ biogas.
\end{abstract}

Keywords: batch digestion, biogas, corn stalk, cow dung, pre-treatment

\section{Introduction}

Agriculture is a key economic sector of the Mekong Delta (MD). However, local authorities have paid a little attention to developing this sector. Livestock production has received little attention because it is mostly carried out by small farmer households and not concentrated in a big area. Therefore, livestock production is characterized by low profitability. In recent years, MD farmers have been increasingly aware of the restructuring of husbandry activities from traditional species of cattle like breeding and dairy cows. According to the General Statistics Office of Vietnam - GSO (2016), the Delta has nearly 5.5 million cows, accounting for $12.95 \%$ of all cows in Vietnam. There are more than 32,000 milk cows in MD, representing $11.31 \%$ of the total milk cows in Vietnam. The number of cows is increasing in recent years in both sectors of livestock husbandry projects and this makes an increase in farmer households' income and profitability of raising livestock. Nevertheless, the number of livestock in each farmer household is small and there is no strategy to collect the manure from the increasing number of scattered stables. Thus, a problem arising in the MD is how to collect and use the waste of all stables in a proper way and to reduce environmental pollution caused by such waste. 
Corn is a main agricultural crop in the MD with the cultivated land of 381,000 hectares (GSO, 2016). The corn is not only used as food for human and animal, but it is also used as raw material for industrial sector (Ngo Huu Tinh et al., 1997). After corn kernel is harvested, a small quantity of corn stalk could be used as feed for animals. Farmers normally burn a large quantity of corn stalk in order to save time and to be able to use the field for a next crop. This practice causes air pollution and a loss of valuable organic material. In the meantime, corn stalks could be used with high efficiency as organic material for biogas production.

As mentioned by Ofoefule et al. (2009), the anaerobic digestion of water hyacinth always needs more time than that of animal dung. Both high values of $\mathrm{C}$ : $\mathrm{N}$ ratio and lignocellulose nature of corn stalk can influence the digestion duration in an anaerobic digester (USDA, 2011). Therefore, corn stalk should be pre-treated before feeding to an anaerobic digestion process. In the previous study, Nguyen Le Phuong et al. (2015b) mentioned that co-digestion of cow dung and corn stalk together produces more biogas in comparison to a digestion of only cow dung. Yang et al. (2003) reported that the biogas production is increasing by $33.7 \%$ when biological method pre-treated corn stalk was used. This study was aimed to investigate the effect of various corn stalk pre-treating time (by effluent from an anaerobic digester) on biogas production when cow dung and corn stalk was co-digested in an anaerobic process.

\section{Methodology}

\subsection{Input materials}

Cow dung (CD) was collected from a cow farm at Long Hoa Ward, Binh Thuy district, Can Tho city. The collected dung was air dried to avoid nutrient loss, then ground (by straw cutter MB TTP 100 with a capacity of $100 \mathrm{~kg} / \mathrm{hour}$ ) and mixed to form a homogeneous material.

Corn stalk (CS) was collected from a corn farm, air dried and cut (by a paper-cutter) into particles with from 8 to 10 $\mathrm{cm}$ length. The corn stalk was pre-treated with effluent from a biogas digester; three durations of the pre-treatment of CS 2-days, 5-days, and 8-days were tested, and the CS was loosened and mixed daily.

The inoculum was collected from the biogas digester that was operating by cow dung at the same site. The inoculum was used as (i) liquid to pre-treat corn stalk, and (ii) adding only one time to each treatment at the starting date as seeding for the digestion process.

\subsection{Experiment setup}

Digester: an anaerobic digester designed for this experiment composing of a PVC bottle with $21 \mathrm{~L}$ volume was used. The bottle was connected to an aluminum bag to collect the gas (Fig. 1). The bottle was filled with $17 \mathrm{~L}$ input material (substrate), thereby lifting $4 \mathrm{~L}$ for gas production so as to avoid the liquid coming to the gas bag. On the top of the liquid layer but inside the digester, one PVC net was placed to limit materials floating up. All bonds from the reactor body (the inlet, outlet, and gas pipe) were connected by soft joints for airtight and watertight. To avoid the development of algae, all digesters were covered with black plastic bags. There were two air valves installed in the pipe between the digester and the gas collecting aluminum bag. Thereby, the gas that flows to the bag can be regulated. Another pipe was placed in the substrate of the digester in order to monitor the digestion activity and gas development.

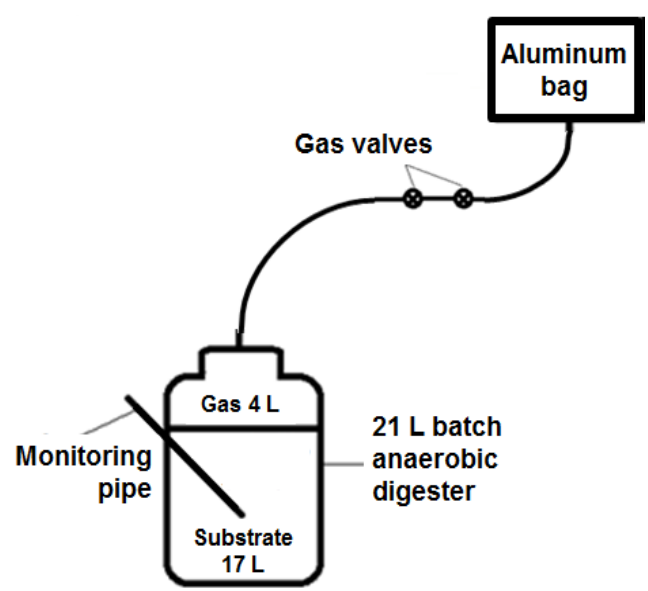

Figure 1. Scheme of experiment apparatus

After the treatments in different durations, the corn stalks were mixed with the ratio of $50 \%$ : 50\% with cow dung based on their volatile solid (VS) values and then filled into the digester (Tab. 1). During the experiment, all of the four treatments run in triplicate. All digesters were manually and gently shaken every day in order to get a homogenous digestion. In this study, the temperature was not controlled so that we could test as real temperature from farmer conditions.

Table 1. Treatments of the experiment (mixing ratio based on the VS value)

\begin{tabular}{lcc} 
Treatment & Treatment time & Mixing ratio \\
\hline NT1 & - & $100 \% C D+0 \% C S$ \\
NT2 & 2-days & $50 \% C D+50 \% C S$ \\
NT3 & 5 -days & $50 \% C D+50 \% C S$ \\
NT4 & 8-days & $50 \% C D+50 \% C S$
\end{tabular}

Note: $C D=$ Cow dung; $C S=$ Corn stalk

According to Eder \& Schulz (2007), the optimal feeding to an anaerobic digester should be $1-4 \mathrm{~g} \mathrm{VS} \times d a y^{-1} \times \mathrm{L}^{-3}$. Based on this suggestion, the material discharged into the experiment was chosen to be $1 \mathrm{~g} \mathrm{VS} \times d a y^{-1} \times \mathrm{L}^{-1}$. In this experiment, the retention time of the material had been set on 45 days. However, on the $45^{\text {th }}$ day of the experiment, during collecting the samples, we found that the corn stalk did not degrade much; therefore, we left a few treatments and monitored them to continue until the $60^{\text {th }}$ day to check the digestion status of the input material. The total material input was $1 \times 17 \times 45=765 \mathrm{~g}$ VS per each digester (Tab. 2). 
Table 2. The quantity of materials used in every digester

\begin{tabular}{lccccccc} 
Ratio of & \multicolumn{3}{c}{ Volatile solid - VS (g) } & \multicolumn{3}{c}{ Total solid - TS (g) } & \multicolumn{2}{c}{ Fresh weight - FW (g) } \\
\cline { 2 - 8 } CD : CS & Corn stalk & Cow dung & Total & Corn stalk & Cow dung & Corn stalk & Cow dung \\
\hline $50 \%: 50 \%$ & 382.5 & 382.5 & 765 & 407.2 & 500.7 & 475.2 & 695.0 \\
$100 \%: 0 \%$ & 765.0 & - & 765 & - & 814.4 & -
\end{tabular}

\subsection{Analytical methods and statistic}

Before the experiment, cow dung and corn stalk were analyzed for values of VS, carbon, and total Kjeldahl nitrogen (TKN) by applying the methods described in the Standard Methods (Tab. 3). Based on these parameters, it was evaluated if the input materials suit for anaerobic digestion process or not. All analyses were conducted at the Biogas Laboratory, College of Environment and Natural Resources, Can Tho University, Vietnam.

Table 3. The physical and chemical characteristics of the input materials used in the experiments

\begin{tabular}{lcrr} 
Parameters & Unit & Cow dung & Corn stalk \\
\hline VS & $\mathrm{mg} / \mathrm{L}$ & 76.4 & 93.9 \\
Carbon & $\mathrm{mg} / \mathrm{L}$ & 19.6 & 52.2 \\
TKN & $\mathrm{mg} / \mathrm{L}$ & 1.0 & 1.2 \\
C : N & - & 19.6 & 43.5
\end{tabular}

The digester's operation parameters of $\mathrm{pH}$, temperature were daily recorded directly by portable equipment (TOA $3 \mathrm{MIP}$ ) through the monitoring pipe attached to each reactor. For alkalinity measurement, a buret method was used according to guideline by APHA, AWWA, WEF (2005).

The first gas samples were collected and recorded after 5 experimental days. Then the biogas produced was recorded by a Ritter gas meter (Germany) with the smallest scale of $20 \mathrm{~mL}$; the biogas compositions were monitored at the same time by a Biogas 5000 gas analyzer (UK). After that, the same procedures were applied for gas recording every three days up to the $60^{\text {th }}$ day of the experiment. The gas recording was expressed at ambient temperature and at stable atmosphere pressure (1004 - 1006 mbar) and at the same time of every testing days.

For the substrate from the experiment before and after digested, the samples were collected to analyze the values of chemical oxygen demand (COD), TKN, total phosphorus (TP), and Faecal Coliform according to the methods described in the Standard Methods (APHA et al., 2005).

For statistical evaluation, Duncan test was applied to determine significant differences among each treatment by using SPSS 16.0 software.

\section{Results and discussion}

\subsection{Biogas production}

\subsubsection{Daily biogas production}

In the first 5 days, the biogas produced was very low, and as result of this, no gas was recorded at this stage of the experiment. In the next 5 days, the highest biogas production was recorded in treatment NT3 $(12.9 \mathrm{~L})$, followed by the treatment NT2 $(9.9 \mathrm{~L})$ and the treatment NT4 (8.9 L). The treatment of NT1 with $100 \%$ cow dung produced the smallest gas volume with $1.9 \mathrm{~L}$ that is a result of low $\mathrm{C} / \mathrm{N}$ ratio in cow dung itself. By the time, the gas volume of codigestion treatments was increasing and reached peak values on the $11^{\text {th }}$ day, and the peak values were $23.9 \mathrm{~L}, 22.4$ $\mathrm{L}$ and $17.9 \mathrm{~L}$ for the treatment of NT2, NT3, and NT4, respectively. For the treatment of NT1, due to a technical problem (the monitoring pipe was not closed), the peak value of $8.7 \mathrm{~L}$ biogas was recorded on the $14^{\text {th }}$ day. After these milestones, the produced gas volume decreased at all treatments but again increased on the $23^{\text {rd }}$ day. On that day, the treatment NT3 produced the highest volume of gas $9.3 \mathrm{~L}$, while the lowest volume recorded in the treatment NT1 $(2.4 \mathrm{~L})$. The increase in the gas volume at this time could be explained by the degradability of cellulose content from input material. As a major chemical component of corn stalk, lignin forms the lignin sheath and surrounds hemicellulose and cellulose, which protects the cellulose and hemicellulose from degradation by cellulase and hemicellulase (Shi et al., 2008). This means at the first 3 weeks, the lignin content from the input material was not yet degradable by the microorganism. By the time, and combination to the outdoor temperature was up to $32.4^{\circ} \mathrm{C}$, the lignin content from input material could be degradable and this caused an increase in gas volume at this time. Since then, the gas produced from all treatments tended to reduce at the end of the experimental phase as the organic compound remaining in the substrate was getting lesser.

\subsubsection{The accumulate biogas volume}

The total gas production after 60 testing days was $69 \pm 8.65$ $\mathrm{L}$ for the treatment NT1, 153.4 $\pm 9.6 \mathrm{~L}$ for the treatment NT2, 206.4 $\pm 8.4 \mathrm{~L}$ for the treatment NT3, and $174 \pm 11.1 \mathrm{~L}$ for the treatment NT4 (Fig. 2). The treatment NT1 (100\% $\mathrm{CD}$ ) had the lowest accumulated gas production but it had a significant difference to the other treatments $(P \leq 0.05)$; this result is in line with the previous study of Yuping et al. (2012). The result of the treatment NT1 could be due to a low $\mathrm{C} / \mathrm{N}$ ratio of cow dung in comparison to the other treatments with co-digestion of cow dung and corn stalk.

Within the co-digestion treatments, the treatment of NT3 produced more biogas volume compared to that of NT2 and NT4 (5\%). In case of treatment NT2, pre-treatment of corn stalk in 2-days was probably too short for microorganisms' activities. There was not enough time for hydrolysis of organic components and to convert them into a monomer form, volatile fatty acid was less produced and this was the reason for the lower amount of biogas production. For 
the treatment NT4, corn stalk was treated with 8-days, it seems that part of cellulose was already degradable. The cellulose remained was not enough for microorganisms in order to convert to biogas form. Therefore, the produced gas volume was also not the highest. The produced biogas

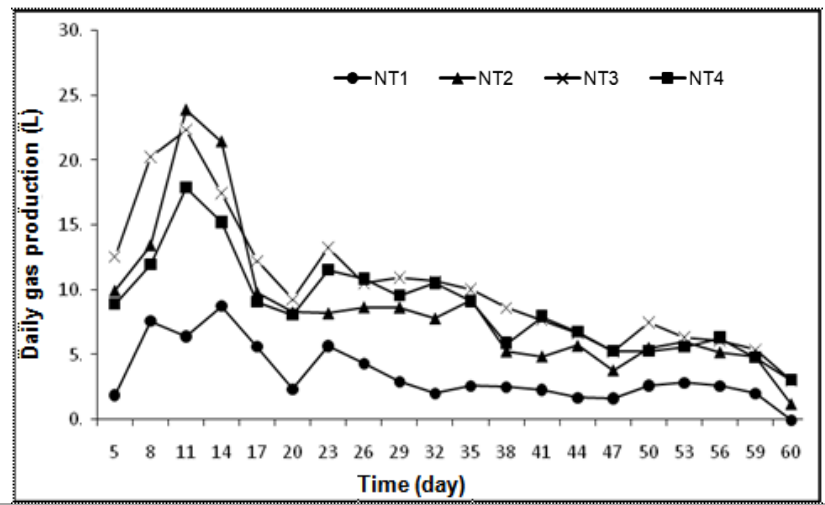

volume was highest in case of treatment NT3; it seems a pre-treatment during 5-days is a suitable time. Hence, 5days could be an optimal duration for pre-treating corn stalks before feeding to an anaerobic digester.

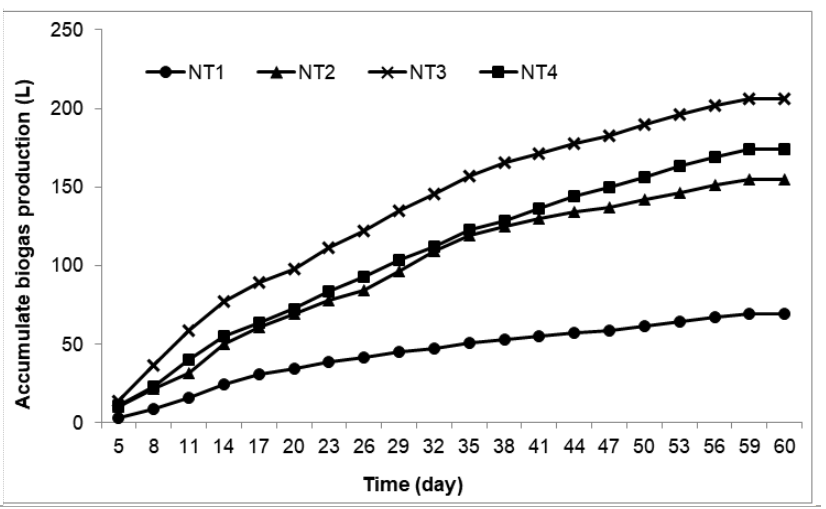

Figure 2. The daily gas production (left) and the accumulated gas production (right) of the four treatments (see Table 1)

\subsubsection{The gas yield}

The biogas yield was calculated based on the difference of the total gas production and the loss of volatile solid $\left(V_{\text {fermented }}\right)$ through a digester process. Up to the end of the experimental period, the biogas yield of treatments NT1, NT2, NT3, and NT4 were respectively 196.1 \pm 5.6 , 392.7 $\pm 9.8469 .8 \pm 10.1$, and 497.1 $\pm 13.3 \mathrm{~L} / \mathrm{kg} \mathrm{VS}$ fermented (Fig. 3). The biogas yield of the treatment NT1 was lowest and significantly different in comparison to the other treatments $(P \leq 0.05)$. There was no significant difference on biogas yields between the other treatments. These results are in line with the studies done by Pedro (2006) and Yuping et al. (2012). Co-fermented cow dung and corn stalk could improve biogas yield in an anaerobic digester and this opens a new opportunity for biogas production for livestock farmers.

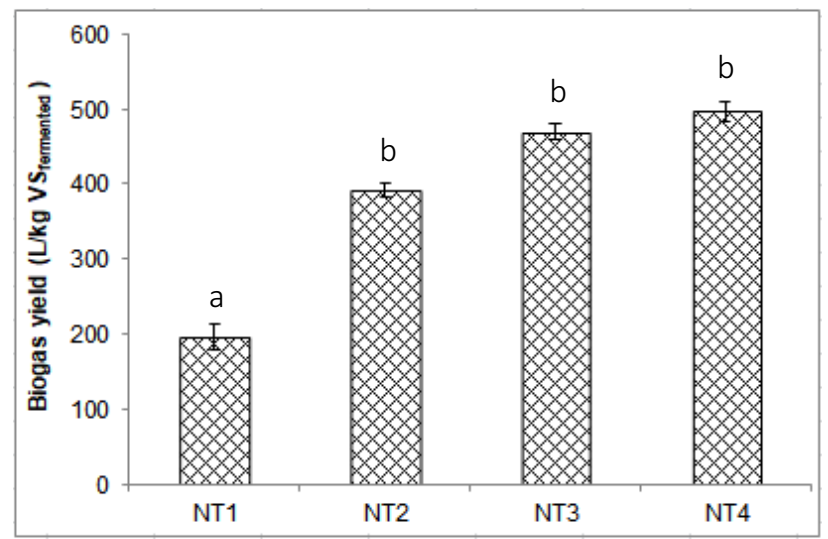

Figure 3. Biogas yield of the four treatments (see Table 1)

Error bars represent the standard deviations values of treatments; different letters indicate significant differences among all treatments $(P=0.05$ Tukey-Test)

\subsubsection{The $\mathrm{CH}_{4}$ content during digestion}

Among biogas components, $\mathrm{CH}_{4}$ is the most important one for energy generation. In the study, the average $\mathrm{CH}_{4}$ content in biogas was measured every 10 days until 60 days digestion in all four treatments (Fig. 4).

Based on the $\mathrm{CH}_{4}$ content recorded, the experimental time could divide into 3 different phases. In the first phase (the first 9 days), the lowest $\mathrm{CH}_{4}$ content was recorded with $11.8-37.6 \%$, while the $\mathrm{CO}_{2}$ content amounted from 12.1 to $51.8 \%$. This first phase is the phase of hydrolysis and acidity in the anaerobic process, the microorganism mainly converts organic matter into volatile fatty acid, causing more $\mathrm{CO}_{2}$ development during this time. The second phase is from day 10 to 33 , the methanogenic microbes grow more and convert volatile fatty acid of the substrate to biogas; thereby, in particular, the $\mathrm{CH}_{4}$ content increased. In this phase, $\mathrm{CH}_{4}$ content was between 47.1 and $52.4 \%$ meanwhile the $\mathrm{CO}_{2}$ amounted from 26 to $37.5 \%$. At the third phase (day 34 to 60 ), there was a reduce trend recorded at $\mathrm{CH}_{4}$ content with $39.9-46.3 \%$, but these values were higher than the $\mathrm{CO}_{2}$ content of $34.4-37.2 \%$. At this time, the amount of the remaining volatile fatty acid was low and methanogenic microbes could not produce as much $\mathrm{CH}_{4}$ as at the second phase.

These results showed that the hydraulic retention time (HRT) of input material should not extend more than 33 days (the preferable time is 30 days). If the HRT extends more than 33 days, the $\mathrm{CH}_{4}$ content will probably decrease and as a result, energy generation will reduce. 


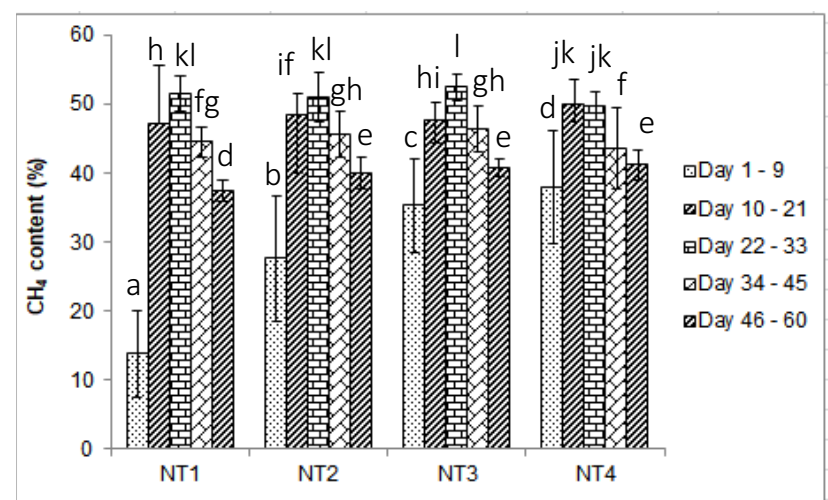

Figure 4. Percentage of $\mathrm{CH}_{4}$ of produced biogas in the four treatments (see Table 1) measured at five dates

Error bars represent the standard deviations values of treatments, different letters indicate significant differences among all treatments $(P=0.05$ Tukey-Test)

In general, the Fig. 4 obviously showed that $\mathrm{CH}_{4}$ content among different treatments was not highly significantly different. One exception was in the first phase, the $\mathrm{CH}_{4}$ content was much lower, in particular in the treatment of NT1 (100\% cow dung) for the 9 first days. From day $10^{\text {th }}$ to the end of the testing phase, there was no significant difference in $\mathrm{CH}_{4}$ content among all treatments.

By co-digestion of cow dung with corn stalk, the $\mathrm{CH}_{4}$ content in this experiment was lower than that was recorded in previous studies done by Tran Trung Tinh et al. (2009), and Tran Sy Nam et al. (2015). In these studies, the authors used different input materials for co-digestion: pig dung with water hyacinth and pig dung with rice straw. However, in this study, the average value of $47.1-52.4 \% \mathrm{CH}_{4}$ content from day $10^{\text {th }}$ to $33^{\text {rd }}$ is good enough for cooking purpose.

\subsection{Temperature, $\mathrm{pH}$, and alkalinity during digestion in all treatments}

Anaerobic digestion is strongly affected by temperature; therefore, in all four treatments, the temperature during the whole digestion period was measured (Fig.5). It can be observed that the average temperature of all treatments was $26.4-31.3^{\circ} \mathrm{C}$, with the respective peak values in the treatments of NT1, NT2, NT3, NT4 were $30.4^{\circ} \mathrm{C}, 30.0^{\circ} \mathrm{C}$, $30.3^{\circ} \mathrm{C}$, and $30.1^{\circ} \mathrm{C}$. These temperature ranges correspond the optimum temperature of mesophilic digester for biogas production $25-40^{\circ} \mathrm{C}$ (Monet, 2003). According to Samir et al. (2010), the activity and growth rate of bacteria decrease by $50 \%$ for each $10^{\circ} \mathrm{C}$ drop in the mesophilic range.

In the weeks 3 to 5 , the recorded temperature values were rather low, in particular, at the day 28 with the treatment of NT2 was $27.4^{\circ} \mathrm{C}, \mathrm{NT3}-26.5^{\circ} \mathrm{C}$, NT4 $-26.3^{\circ} \mathrm{C}$; at the day 35 , the temperature was only $26.4^{\circ} \mathrm{C}$ recorded in the treatment NT1. The experiments were carried out in the rainy season; therefore, the temperature was obviously influenced by very low air temperature outdoors for several days.

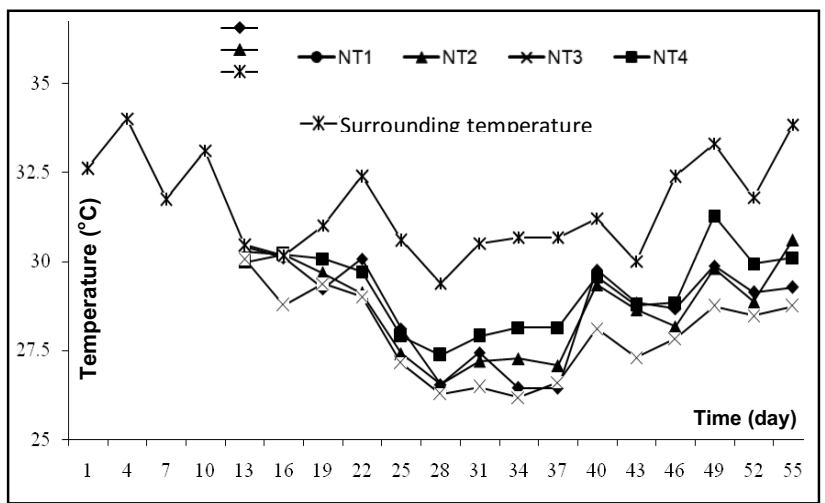

Figure 5. Temperature values during the digestion of the four treatments (see Table 1)

The $\mathrm{pH}$ of the anaerobic digestion process is another parameter that has a significant effect on the digestion process (Fig. 6). It can be observed that the $\mathrm{pH}$ in all treatments was almost in the optimum $\mathrm{pH}$ range in an- anaerobic digesters with 6.0 to 7.5 (Capri \& Marais, 1975). For treatment of $100 \%$ cow dung, the initial $\mathrm{pH}$ value was 7.4 and got a peak value at day 10 that was higher than for the co-digestion treatments a general tendency of stable values of 7.1 - 7.6 after 5 weeks is confirmed. In line with NT1, the $\mathrm{pH}$ peak values of co-digestion treatments (NT2 - 7.2, NT3 - 6.5, and NT4 - 7.0) were lower with a peak value on day 10 , then stabilizing in range of 7.0 - 7.4 from the day 35 to the end of the testing time. This indicated a better $\mathrm{pH}$ profile of the co-digestion during anaerobic digestion and more optimum range of $\mathrm{pH}$ values compared to solely digestion.

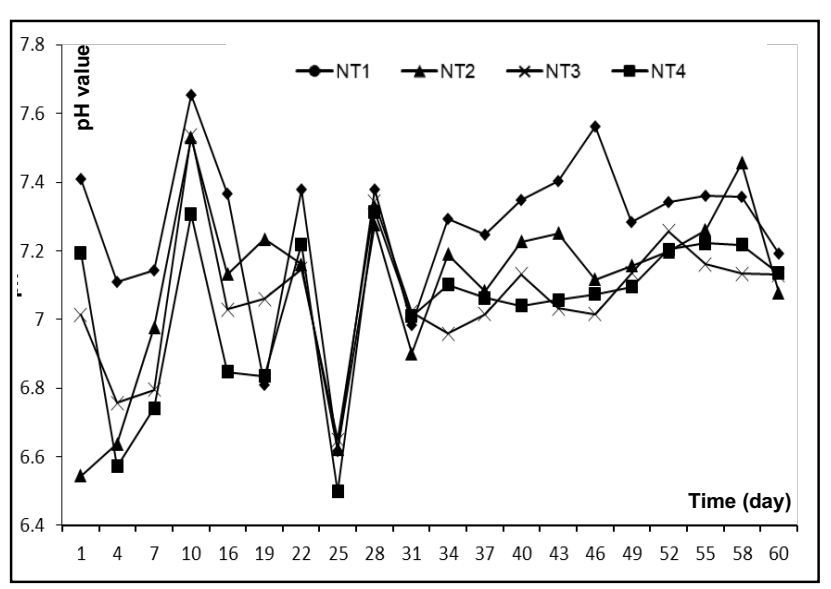

Figure 6. $\mathrm{pH}$ values during the digestion of the four treatments (see Table 1)

The buffering capacity of an anaerobic digester is determined by the amount of alkalinity present in the system. Sufficient alkalinity is the main source of buffering capacity to maintain the system's $\mathrm{pH}$ in the optimum range. In this experiment, the initial alkalinity concentration of co-digestion treatments was from 2060 to $2580 \mathrm{mg} \mathrm{CaCO}_{3} / \mathrm{L}$, then increasing to 2580 - $2900 \mathrm{mg} \mathrm{CaCO} / \mathrm{L}$ after 60 digestion days. For treatment of $100 \% \mathrm{CD}$, the latter alkalinity concentration was $3400 \mathrm{mg} \mathrm{CaCO} / \mathrm{L}$, meanwhile, at the beginning of the experiment, the alkalinity was $3120 \mathrm{mg} \mathrm{CaCO}_{3} / \mathrm{L}$ 
(Fig. 7). The mixing of corn stalk with cow dung in the anaerobic process reduces alkalinity concentration compared to the $100 \%$ cow dung treatment that caused a negative effect on the stable operation of digesters. These results are similar to those of the study of Labatut \& Gooch (2012) showing that cow manure can play an important role in co-digestion operations by increasing the $\mathrm{pH}$ and buffering capacity of the mixture when easily degradable industrial wastes are used as co-substrates. In the range of 2060 - $3400 \mathrm{mg} \mathrm{CaCO} / \mathrm{L}$, the alkalinity concentration of this study was in an optimum range for anaerobic digestion process of 1500 - $5000 \mathrm{mg} \mathrm{CaCO} / \mathrm{L}$ (Le \& Nguyen, 2013).

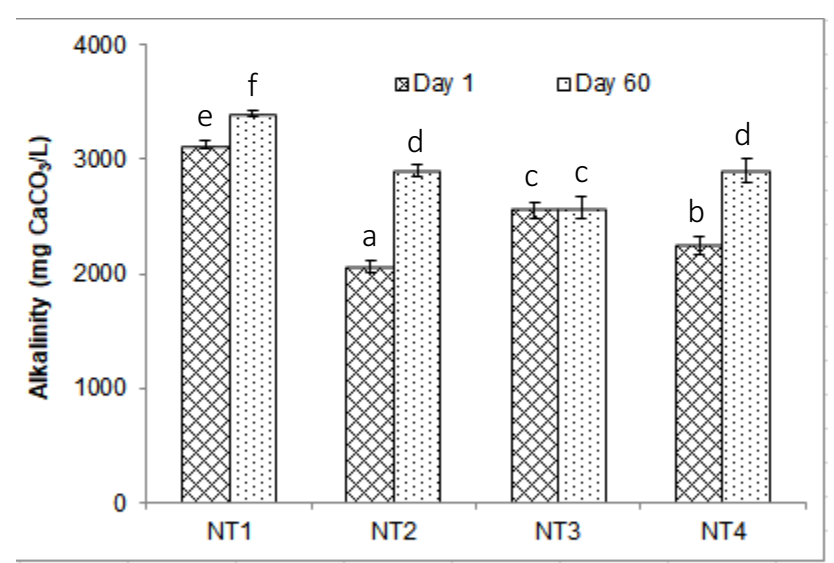

Figure 7. Alkalinity values of the four treatments (see Table 1) at the beginning and after 60 days

Error bars represent the standard deviations values of treatments, different letters indicate significant differences among all treatments $(P=0.05$ Tukey-Test)
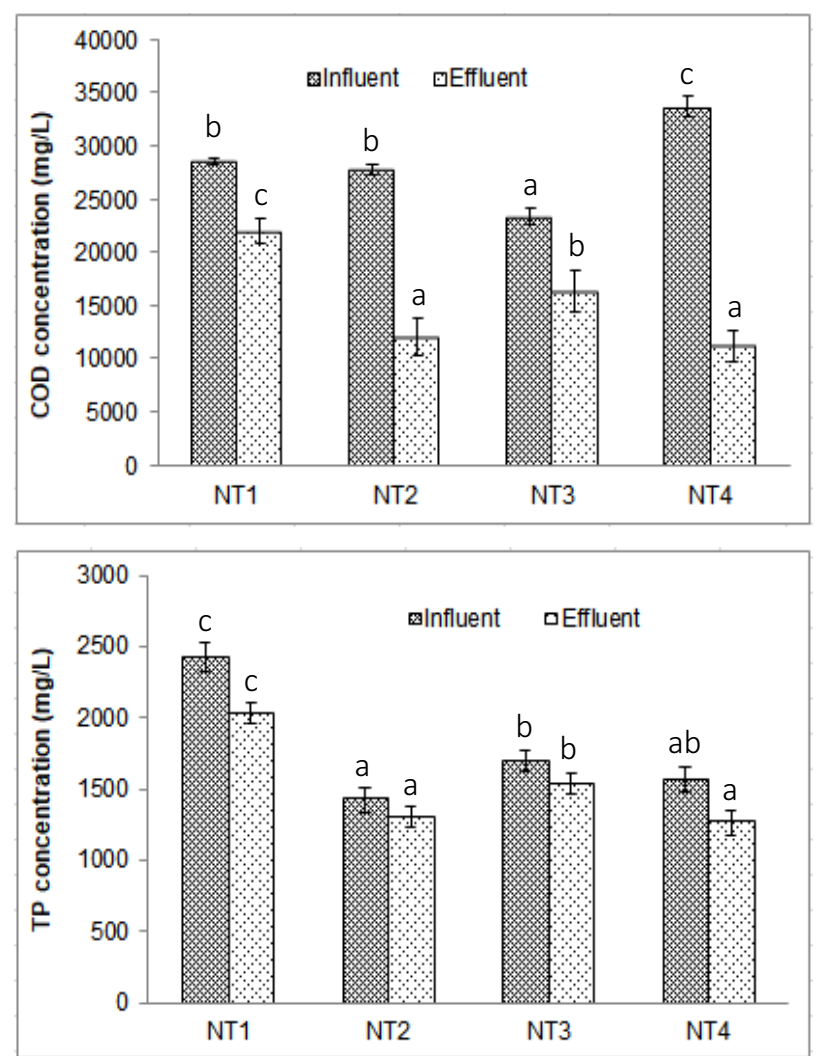

\subsection{Treatment efficiency}

Anaerobic digestion of organic matter to biogas has developed from a method of waste treatment. In this experiment, the waste that is needed to be treated is pig dung, and the substrates before (influent) and after (effluent) the digestion process were collected and analyzed to test treatment efficiency of cow dung. The initial substrate was rich on organic matter of COD from 23300 to 33700 $\mathrm{mg} / \mathrm{L}$, the high nutrient content of TKN from 650 to 850 $\mathrm{mg} / \mathrm{L}$, TP from 1429 to $2430 \mathrm{mg} / \mathrm{L}$, and the Faecal Coliform from 50000 to 320000 MPN/100 mL (Fig. 8). After 60 days of digestion, the best treatment efficiency was recorded on the Faecal Coliform with up to $94 \%$, but the worse one was from TP with less than 19\%. The treatment efficiency of TKN was from 25.9 to $33.3 \%$, and that of COD from 56.9 to $66.9 \%$.

After digestion process, TKN that remained in the effluent - called digestate - was from 375 to $458 \mathrm{mg} / \mathrm{L}$, TP from 1270 to $2030 \mathrm{mg} / \mathrm{L}$; COD from 11200 to $21900 \mathrm{mg} / \mathrm{L}$, and Fecal Coliform from 2200 to $17000 \mathrm{MPN} / 100 \mathrm{~mL}$. The high organic and high nutrient remaining from the effluent causes pollution for receiving water bodies. However, as recommended by Nguyen Vo Chau Ngan (2012), Nguyen \& Fricke (2014), it could be favorable to reuse the digestate as organic fertilizer for agriculture and/or aquaculture crops. However, it is a warning that bacteria could remain on a vegetable that is irrigated by digestate and such vegetable should not be eaten raw (Nguyen Vo Chau Ngan et al., 2015).
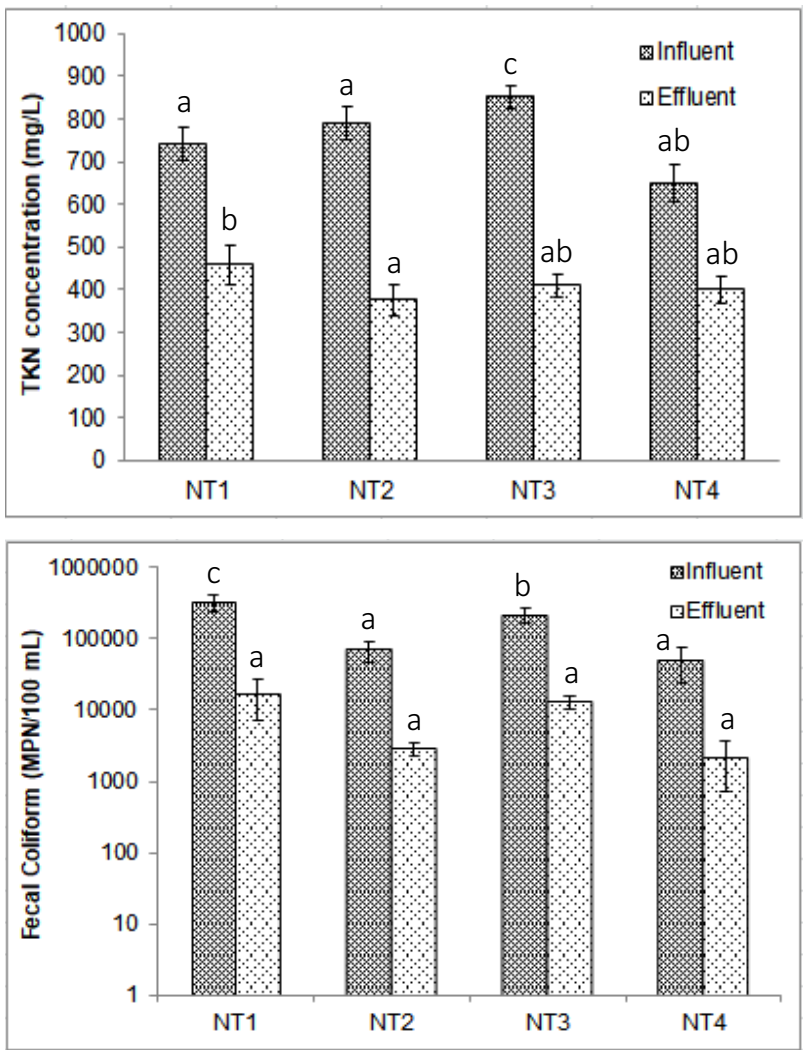

Figure 8. Comparing influent and effluent of COD, TKN, TP and Faecal Coliform of the four treatments (see Table 1)

Error bars represent the standard deviations from influent and effluent of treatments, different letters indicate significant differences among all treatments ( $P=0.05$ Tukey-Test) 


\section{Conclusions}

In this study, three types of treatment duration (2-days, 5days, and 8-days) of corn stalk were selected for the experiments of anaerobic co-digestion of cow dung and corn stalk and compared with the control (100\% cow dung) as the first treatment. There was a significant difference between the 5-days treated treatment and the other treatments on the total gas produced within the testing period. However, in case of gas yield and gas composition, there was no significant difference among all treatments. In all treatments, the $\mathrm{CH}_{4}$ concentration reached a good quality for cooking purpose after 10-days of digestion. Therefore, a 5-days treatment could be a preferable option for corn stalk to be supplementarily loaded to an anaerobic digester in combination with cow dung.

Since organic and nutrient matter remains high in digestate, it could be applied as an organic fertilizer to agriculture and/or aquaculture cultivations.

Acknowledgment. The authors acknowledge the financial support of the project "Sustainable Production of Biogas from Waste Rice Straw" by DANIDA (Code 11-016AU).

\section{References}

[1] APHA, AWWA, WEF (2005). Standard methods for the examination of water and wastewater, 21st ed. American Public Health Association, American Water Works Association, Water Environment Federation. Washington DC.

[2] Capri M. G., Marais G. v. R., 1975. pH adjustment in anaerobic digestion. Water Research. 9(3): 307-313.

[3] Eder B., Schulz H., 2007. Biogas-Praxis: Grund-lagen, planung, anlagenbau, beispiele, wirtschaft-lichkeit. Ökobuch Magnum.

[4] GSO - General Statistics Office of Vietnam, 2016. Statistical yearbook of Vietnam 2015. Statistical Publishing House.

[5] Labatut R. A., Gooch C. A., 2012. Monitoring of anaerobic digestion process to optimize performance and prevent system failure. Proceedings of Got Manure? Enhancing Environmental and Economic Sustainability. 209-225.

[6] Le Hoang Viet, Nguyen Huu Chiem, 2013. Solid waste treatment and management. Can Tho University Publishing House (in Vietnamese).

[7] Monet F., 2003. An introduction to anaerobic digestion of organic wastes. Remade Scotland.

[8] Ngo Huu Tinh, Tran Hong Uy, Vo Dinh Long, Bui Manh Cuong, Le Qui Kha, Nguyen The Hung, 1997. Corn tree - Original source, genetic diversity, and growing process. Agricultural Publishing House (in Vietnamese).

[9] Nguyen Le Phuong, Le Thi Thao Quyen, Nguyen Thi
Ngoc Huyen, Nguyen Thi Nhu Huynh, Nguyen Thi Diem Trang, Nguyen Vo Chau Ngan, 2015a. Biogas production from corn stalk - Effects of size. Nha Trang University Journal of Fisheries Science and Technology, Special issue. 69-75.

[10] Nguyen Le Phuong, Truong Minh Chau, Vo Van Du, Lam Thanh Ai, Nguyen Vo Chau Ngan, 2015b. Effects of mixing ratios to biogas production of anaerobic codigestion of cow manure in a combination of corn stalks or aquatic weed. Can Tho University Journal of Science. Special issue on Environment and Climate Change, 71-79 (in Vietnamese).

[11] Nguyen V. C. N., Fricke K., 2014. Application of co-anaerobic digester's effluent for sustainable agriculture and aquaculture in the Mekong Delta, Vietnam. Environmental Technology, 36(23): 2991-2999.

[12] Nguyen Vo Chau Ngan, 2012. Promotion of Biogas Plant Application in the Mekong Delta of Vietnam. Ph.D. dissertation. Technical University of Braunschweig, Germany.

[13] Nguyen Vo Chau Ngan, Hong Minh Hoang, Phan Ngoc Linh, Nguyen Thi Nhat Linh, Pham Cha My, Kieu Thanh Nguyet, Pham Minh Tri, 2015. Co-benefits from applying co-digesters bio-slurry to farming activities in the Mekong Delta. Health Environment, 1: 30-44.

[14] Ofoefule U., Uzodinma E. O., Onukwuli O. D., 2009. Comparative study of the effect of different pretreatment methods on biogas yield from Water Hyacinth (Eichhornia crassipes). International Journal of Physical Sciences. 4(8): 535-539.

[15] Pedro Aphalo, 2006. Biogas Production from Energy crops and Crop Residues. The University of Jyväskylä.

[16] Samir K. K., Rao Y. S., Tian C. Z., Buddhi P. L., Tyagi R. D., Kao C. M., 2010. Bioenergy and biofuel from biowastes and biomass. Reston: American Society of Civil Engineers.

[17] Shi J., Chinn M. S., Sharma-Shivappa R. R., 2008. Microbial pretreatment of cotton stalks by solid state cultivation of Phanerochaete chrysosporium. Bio-resource Technology, 99(14): 6556-6564.

[18] Tran Sy Nam, Nguyen Phuong Chi, Nguyen Huu Chiem, Le Hoang Viet, Nguyen Vo Chau Ngan, Kjeld Ingvorsen, 2015. Effect of biological pretreatment of water hyacinth on biogas production in batch anaerobic digestion with pig manure. Can Tho University Journal of Science. Special issue on Environment and Climate Change, 102-110 (in Vietnamese).

[19] Tran Trung Tinh, Nguyen Van Dung, Do Ngoc Duy Phuong, Nguyen Huu Phong, 2009. Study on producing electricity from water hyacinth. Proceeding from Workshop "VIE020 - Production of Aqua and Agricultural Products and Renewable Energy from Water Hyacinths and Waste". Can Tho University (in Vietnamese). 
[20] USDA, 2011. Carbon to nitrogen ratios in cropping systems. Accessed on https://www.nrcs.usda.gov/wp s/PA_NRCSConsumption/download?cid=nrcs142p2 052823\&ext=pdf

[21] Yang Dong Yan; Li Xiu Jin; Gao Zhi Jian; Wang Yong Wu, 2003. Improving biogas production of corn stalk through chemical and biological pretreatment: a pre- liminary comparison study. Transactions of the Chinese Society of Agricultural Engineering. 19(5): 209213.

[22] Yuping Dong, Shuxia Zhoua, Yulin Zhang, 2012. Pretreatment for biogas production by anaerobic fermentation of mixed corn stover and cow dung. Energy, 46(1): 644-648. 